\title{
Force Majeure and Hardship Clauses in the Iraqi Kurdistan Region Oil and Gas Contracts: A Comparative Study
}

\author{
Mohsin Shareef Salih \\ Lecturer \\ Law Department \\ Faculty of Law, Political Science and Management \\ Soran University \\ Kurdistan Region-Iraq \\ Dr. Akram Yamulki \\ Professor \\ Law Department \\ Faculty of Law and International Relations \\ Cihan University-Erbil \\ Kurdistan Region-Iraq
}

\begin{abstract}
Oil and gas contracts are long-term agreements that cover long periods. In such contracts, circumstances may change with time, especially in developing countries. To protect from future unforeseen circumstances which are beyond the control of contracting parties, they insert force majeure and hardship clauses in their contracts. This article aims to evaluate and analyse force majeure and hardship clauses in oil and gas contracts. It focuses on the Kurdistan Regional Government's production sharing contracts and provides a comparison with some countries' oil and gas contracts. The research method is adopted in this article includes the comparative analysis method. The research is conducted through an extensive study of the relevant literature.
\end{abstract}

Key words: Force Majeure clause, Hardship clause, Oil and gas Contract, Kurdistan Regional Government (KRG) and Production Sharing Contracts (PSCs).

\section{Introduction}

Oil and gas contracts are long-term contracts and need huge capital investment. In the life of these contracts, circumstances, economics, and governments invariably change can often lead to a dispute. Any Oil and Gas contract contains some clauses to prevent and resolve the disputes. When difficulties and conflicts arise in the contracts, contractual clauses become important. For this purpose there are a lot of clauses in different names that a host government and an international oil company can insert in their contracts. This article considers the inclusion of force majeure and hardship clauses for the prevention and resolution of disputes in the Iraqi Kurdistan Region oil and gas contracts. It advances the understanding of these clauses by defining, determining their effectiveness, and the way of drafting in oil and gas contracts. It considers the clauses in the Kurdistan Regional Government's (KRG) Production Sharing Contracts (PSCs) and compares this with some countries' oil and gas contracts.

\section{Overview of the Force Majeure Clause and its Inclusion in the KRG's Oil and Gas Contracts}

The force majeure clause in an oil and gas contract excuses a party from failing to fulfill its contractual obligations because of unexpected occasions beyond its control. This section provides a clear understanding of the force majeure clause and explores this clause in KRG's oil and gas contracts with comparing to certain countries.

\subsection{Definition of Force Majeure Clauses}

There are several definitions for the force majeure clause. For example, it has been defined as a clause which "entitles a party to suspend or terminate the contract on the occurrence of an event which is beyond the control of the parties and which prevents, impedes, or delays the performance of the contract." ${ }^{1}$ The force majeure clause is also defined by Langenkamp as:

\footnotetext{
${ }^{1}$ Ewan McKendrick, Contract Law ( ${ }^{\text {th }}$ edn, Oxford University press, 2012) 397 102
} 
A contract clause providing that failure to perform shall not be deemed a contract breach, and/or the performance of the covenants shall be excused when the failure of performance is owing to causes set forth in the clause. Such clauses usually list acts of God; adverse weather; compliance with federal, state, or municipal laws; wars; strikes; and other contingencies over which the contracting party has no control. ${ }^{2}$

Thus, the force majeure clause excuses a contracting party from its contractual obligations due to unforeseeable events beyond its control ${ }^{3}$. This clause provides that, non-performance or delay the performance of the contract is no breach, while an event occurs, which is beyond the control of the parties. The force majeure clause usually determines the events.

\subsection{Requirements for Triggering a Force Majeure Clause}

Relying on a force majeure clause often requires the realisation of one or more of the following conditions:

1) the force majeure event is an impediment beyond the control of the claiming party;

2) the event prevents or delays performance under the contract, in whole or in part;

3) the event makes performance under the contract imprudent, substantially more difficult or substantially more expensive;

4) the event was not due to fault or negligence of the claiming (or non-performing ) party; and

5) the party claiming excused non-performance must have exercised reasonable diligence to overcome or remove the force majeure event. ${ }^{4}$

\subsection{Consequences of Force Majeure Clauses}

In a contract, parties can insert the force majeure clause to protect from unforeseeable events. The direction of courts that focus on explicit provisions must be supported because complete and explicit contracts reduce the ability of judges to impose unwanted provisions. Inserting precise and explicit clauses in international contracts can result in clear and conclusive results that are considered by the parties. Through drafting methods of clauses in a contract, parties determine the limitation and effects of the force majeure clause. In the case of the occurrence of unforeseen events, such a clause provides a great opportunity for the parties to determine the nature and scope of contract enforcement without the need to recourse to domestic law. Besides, this clause with compare to rules of domestic law in implication is more flexible. If the discussed clause ideally drafted and prepared, the courts will be prevented from judicial interpretation. On the contrary, if these clauses are not well-drafted, the courts interpret the clauses very narrowly and ignore the intentions of both parties. ${ }^{5}$

The role of the force majeure clause is more important in international commercial contracts because parties usually are from different countries and subject to different legal systems. Regardless of the different methods and deficiencies in the domestic legal systems, the distance between the parties of the contract is also an important factor to consider when setting the force majeure clause. The distance between the parties raises special obstacles such as, war, the intervention of governments, inflation, and so on, which impede the performance of the contract. Thus, force majeure clauses can protect parties otherwise required to perform contracts when circumstances make performance significantly more difficult or even impossible. The effectiveness of these clauses, however, depends on their construction to a large extent. The courts must give effect to the parties' intentions reflected by the language they use when the terms of a contract are explicit. Instead of leaving the interpretation of their contracts to the courts, it would be prudent for the parties to state their desire clearly and unambiguously in the contract so that they can adequately protect themselves from future contingencies. ${ }^{6}$

\subsection{Drafting Force Majeure Clauses}

The force majeure clause is a mechanism that before the occurrence of an event, resolves any dispute and conflict in the future. Therefore, in drafting this clause, certain important points should be considered. The initial step for contract drafters to draft an effective majeure clause is to obtain a clear picture of the commercial relationship underlying a given contract.

\footnotetext{
${ }^{2}$ Robert Dobie Langenkamp, Handbook of oil industry Terms and phrases ( $6^{\text {th }}$ edn, Penn Well, 2014) 191

${ }^{3}$ Mohsin Shareef Salih and Rdhwan Shareef Salih, 'Strategy of Oil Contract Negotiation' (2015) 6 (9) International Journal of Business and Social Science168

${ }^{4}$ Don Greenfield \& Bob Rooney, 'Aspects of International Petroleum Agreements' (1999) 37 Alberta Law Review 352

${ }^{5}$ Rene David, 'Frustration of Contract in French Law' (1946) 28 (3/4) Journal of Comparative Legislation and International Law <https://www.jstor.org/stable/754645?seq=1\#metadata_info_tab_contents> accessed 20 November 2019

${ }^{6}$ Greenfield \& Rooney, Op.Cit., 373
} 
Thus, parties of a contract are required to take into account several critical considerations, including a proper understanding of the law governing the contract, the requirements of the party on whose behalf the contract is drafted, and the specialties of the pertinent part of the industry concerned. ${ }^{7}$

In drafting such a clause, the force majeure events should be determined and defined. The legal components for the qualification of an event of force majeure are largely the same in most systems of law. These components are:

1) The event is external,

2) It could not be predicted or prevented and,

3) It makes the fulfillment of a contractual obligation impossible at all or for a certain time. ${ }^{8}$

However, there is not a single universally accepted definition for force majeure in all legal systems. It has different definitions such as unforeseeability, impossibility, insurmountability, and externality that applied differently from one national legal system to another.Particular attention should, therefore, be paid to present a definition of the force majeure as accurately as possible. A review of the current contract practice in the petroleum industry indicates two different methods that have been implemented by this group of contracts to define force majeure events. There is a small range of oil and gas contracts that leave the task of defining force majeure to a special system of national or international law. ${ }^{9}$

On the other hand, in most oil and gas contracts, parties provide a detailed description of situations that can represent a condition of force majeure. Such a description usually consists of three different parts: a general definition of force majeure, a list of specific force majeure events and a phrase such as or any other causes whether or not similar to the foregoing. ${ }^{10}$

The events which cause the implementation of force majeure need to be determined. The mean of force majeure is broader than the act of God, as the latter signifies events without human intervention due to natural causes. However, force majeure events are not limited to those which occur in nature and can consist of:

1) Acts of war or insurrection, for example, declared or undeclared war, civil war, revolution, guerilla activity, or any other antagonistic act, whether inside or outside to the host country;

2) Scarcities or non-accessibility of materials, parts, fuel, labor, or transportation;

3) Laubor disputes such as strikes, lockouts, or any other laubor struggle;

4) Government action, such as enacting laws or issuing regulations and orders by any governmental body that has jurisdiction over the parties or the operations hereunder; or

5) Government inaction, such as failure or delay in giving visas, import licenses, environmental and other government approves or authorizations required to fulfill contract operations. ${ }^{11}$

Since force majeure clauses are considered by their nature to protect against an unforeseen possibility, they cannot be limited to an exact definition or a restricted list of examples. Thus, if particular force majeure events are mentioned, it should be made clear in the contract that the list is included as for instance and not as a limitation. ${ }^{12}$ Therefore the force majeure clause, after listing events, should mention a phrase such as or any other causes whether or not similar to the foregoing.

Consequently, the force majeure clause must be obvious, clear, and complete. This clause should be designed in a way that eliminates deficiencies of national law. In drafting the force majeure clause in oil and gas contracts, it requires enough precision and high skill. By the correct formulation of Force Majeure clauses, the parties are equipped with a tool that will release them from any wandering in the event of an unpredictable event. The fact that, despite setting the force majeure clause, still certain factors will threaten the performance of the contract, should not preclude the parties from attempting to set the clause.

\footnotetext{
${ }^{7}$ Mahmoud Reza Firoozmand, 'Force Majeure Clause in Long-Term Petroleum Contracts: Key Issues in Drafting'(2006) 24/3 Journal of Energy \& Natural Resources Law 423

${ }^{8}$ Werner Melis, 'Force Majeure and Hardship Clauses in International Commercial Contracts in View of the Practice of the ICC Court of Arbitration' (1984) 1 Journal of International Arbitration <http://www.kluwerlawonline.com/abstract.php?area=Journals\&id=JOIA1984023> accessed 7 December 2019

${ }^{9}$ Firoozmand,Op.Cit, 426

${ }^{10}$ Ibid, 427

${ }^{11}$ Greenfield \& Bob Rooney,Op.Cit, 375.

${ }^{12}$ Ibid.

104
} 
The contract parties in their relative negotiations can minimise these risks and their effectiveness. More importantly, the parties are not in any doubt about the nature and scope of their duties regarding their respective responsibilities when the contract is not implemented. For achieving these goals, the clause must be clear and complete. The parties need to include the contract, what is in their consideration in a clear and obvious manner. In order to ensure that this clause is not subject to different interpretations, it must be carefully reviewed by specialised lawyers.

\subsection{Force Majeure Clauses in KRG's PSCs}

Article 40 in KRG production sharing contracts regulates force majeure, it states:

40.1 No delay, default, breach or omission of the CONTRACTOR in the execution of any of its obligations under this Contract shall be considered a failure to perform this Contract or be the subject of a dispute if such delay, default, breach or omission is due to a case of Force Majeure. In such event the CONTRACTOR shall promptly notify the GOVERNMENT in writing and take all reasonably appropriate measures to perform its obligations under this Contract to the extent possible. The time resulting from any such delay or curtailment in the execution of such obligations, increased by the time necessary to repair any damage resulting from or occurred during such delay or curtailment, shall be added to any time period provided under this Contract (including the Exploration Period and any extension thereto, any Sub-Period and any extension thereto and any development period and any extension thereto). The parties shall meet as soon as possible after the notification of Force Majeure with a view to using reasonable endeavours to mitigate the effects thereof.

40.2 For the purpose of this Contract, "Force Majeure" means any event that is unforeseeable, insurmountable and irresistible, not due to any error or omission by the CONTRACTOR but due to circumstances beyond its control, which prevents or impedes execution of all or part of its obligations under this Contract. Such events shall include the following:

(a) war, whether declared or not, civil war, insurrection, riots, civil commotion, terrorism, any other hostile acts, whether internal or external;

(b) strikes or other labour conflicts;

(c) accidents or blowouts;

(d) quarantine restrictions or epidemics;

(e) any act, event, happening or occurrence due to natural causes, in particular, but without limitation, floods, storms, cyclones, fires, lightning, or earthquakes;

(f) environmental restrictions, which the GOVERNMENT has not notified to the CONTRACTOR;

(g) except in respect of the GOVERNMENT and/or any Public Company which may be a contractor entity, any acts or orders of the GOVERNMENT, any minister, ministry, department, sub-division , agency, authority, council, committee or other constituent element thereof, any corporation owned and/or controlled by any of the foregoing; and

(h) any acts or orders of any other government claiming or asserting jurisdiction over the subject matter of this Contract, any minister, ministry, department, sub-division, agency, authority, council, committee or other constituent element thereof, or any corporation owned and/or controlled by any of the foregoing.

40.3 The intention of the parties is that Force Majeure shall receive the interpretation that complies most with prudent international petroleum industry practice. Force Majeure affecting a CONTRACTOR entity or an affiliated company of a contractor Entity shall be deemed Force Majeure affecting the CONTRACTOR if the consequence of such Force Majeure prevents the performance of any CONTRACTOR's obligations under this Contract. ${ }^{13}$

From this article, it appears that the force majeure clause in KRG production sharing contracts is well-written, but it is too long. Firstly, it clarifies that in a case of force majeure delay, default, breach, or omission of the contractor is not considered as a failure to perform the contract or the subject of a dispute. After that, it mentions notifying the government by the contractor in the event of force majeure. By the notification of force majeure, parties shall meet as soon as possible to mitigate the effects thereof. Then, the article determines the mean and the events of force majeure, despite presenting events in a list, still, in certain events, they are examples rather than limitation.

\subsection{Force Majeure Comparison}

a) Indonesian PSCs

In the Indonesian PSC, the force majeure is stipulated in Section I (Scope and Definitions), 1.2.10 as:

Force majeure means delays or defaults in performance under this Contract caused by circumstances beyond the control and without the fault or negligence of PERTAMINA and/or CNTRACTOR that may affect economically or otherwise the continuing of operations under this Contract, including but not restricted to acts of God or the public

\footnotetext{
${ }^{13}$ The Production Sharing Contract, Dohuk Block, 2008, between the Kurdistan Regional Government of Iraq and DNO Iraq As, Art 40.
} 
enemy, perils of navigation, fire, hostilities, war (declared or undeclared), blockade, labor disturbances, strikes, riots, insurrection, civil commotion, quarantine restrictions, epidemics, storms, earthquakes, or accidents. ${ }^{14}$

Force majeure clause is not mentioned in the Indonesian PSC as a separate clause, however, the mean of force majeure is clarified in the section of scope of definitions of the contract. It is well- defined and the events are determined by examples, not limitations. Obligations of parties in the case of force majeure are explained clearly in section xv (15.3 Suspension of Obligation) as below:

15.3.1 Any failure or delay on the part of either Party in the performance of their obligation or duties hereunder shall be excused to the extent attributable to Force Majeure.

15.3.2 If operations are delayed, curtailed or prevented by such causes, then the time for carrying out the obligations thereby affected, the term of this Contract and all rights and obligations hereunder shall be extended for a period equal to the period thus involved.

15.3.3 The Party whose ability to perform its obligations is so affected shall notify the other Party thereof in writing, stating the cause and both shall do all reasonably within their power to remove such cause. ${ }^{15}$

\section{b) Nigerian PSCs}

In the Nigerian PSC, the force majeure clause is well-designed. It defines force majeure and determines force majeure events by examples not restricted events. Then it organizes the issue of extension of time in case of force majeure to carry out obligations under the contract. The clause also regulates the duty of a party who is unable to perform its obligations due to force majeure to notify the other party. Force majeure clause in Nigerian PSCs is designed as below:

Article20

\section{FORCEMAJEURE}

20.1 Any failure or delay on the part of either Party in the performance of its obligations or duties under this Agreement shall be excused to the extent attributable to force majeure. A force majeure situation $\mathrm{s} \mathrm{h}$ a 11 include delays, defaults or inability to perform under this Agreement due to any event beyond the reasonable control of either Party. Such event may be, but is not limited to, any act, happening, or occurrence due to natural causes; and acts or perils of navigation, fire, hostilities, war (declared or undeclared), blockage, labour disturbances, strikes, riots, insurrection, civil commotion, quarantine restrictions, epidemics, storms, floods, earthquakes, accidents, blowouts, lightning, and, acts of or orders of Government.

20.2If operation is delayed, curtailed or prevented by force majeure, then the time for carrying out the obligation and duties thereby affected, and rights and obligations hereunder, shall be extended for a period equal to the period thus involved.

20.3 The Party whose ability to perform Its obligations is so affected shall promptly notify the other Party thereof not later than forty-eight (48) hours after the establishment of the start of Force Majeure, stating the cause, and the Parties shall do all that is reasonably within their powers to remove such cause. ${ }^{16}$

\section{Overview of the Hardship Clause and its Inclusion in the KRG's Oil and Gas Contracts}

A hardship clause can play a key role in a long-term contract in preventing a strict application of the principle of sanctity of contracts results in intolerable consequences. Negotiators, however, need to be aware that such a clause will always be delicate to implement, even when it is drafted excellently. ${ }^{17}$ Parties of an oil and gas contract may be aware of the risks involved in the contract and so, they will negotiate the inclusion of clauses to manage these risks, attempting to predict and deal with unforeseen circumstances that essentially alter the contractual equilibrium of the contract.

One of these clauses managing the risk of altered circumstances is the hardship clause, so the clause is provided for a pre-established contractual solution to mitigate or eliminate the consequences of such changed circumstances. This

\footnotetext{
${ }^{14}$ Production Sharing Contract for Yapen Block, 1999, Between Perusahaan Pertambangan Minyak Dan Gas Bumi Negara (Pertamina) and Apex(Yapen) LTD.

${ }^{15}$ Ibid.

${ }^{16}$ Production sharing Agreement, Strategic Alliance Agreement Between Nigerian Petroleum Development Company

Limited and Atlantic Energy Drilling Concepts Nigeria Limited for the Development and Production of OML 30, 2011.

17 Marcel Fontaine \&Filip De Ly, Draftin International contracts: An Analysis of Contract Clauses (Transnational Publishersp2006), 492 
section defines the hardship clause and clarifies the important role of the clause in oil and gas contracts. It investigates the hardship clause in KRG's PSCs and compares it with various countries' oil and gas contracts.

\subsection{Definition of Hardship Clauses}

Hardship clauses attempt to protect long-term contracts from the impact of unanticipated changes beyond the control of any contracting party that might imperil the balance of effort and reward on which their original agreement depended. The International Institute for the Unification of Private Law (UNIDROIT) in principles of international commercial contracts 2016 in article 6 defines hardship as:

There is hardship where the occurrence of events fundamentally alters the equilibrium of the contract either because the cost of a party's performance has increased or because the value of the performance a party receives has diminished, and

(a) The events occur or become known to the disadvantaged party after the conclusion of the contract;

(b) The events could not reasonably have been taken into account by the disadvantaged party at the time of the conclusion of the contract;

(c) The events are beyond the control of the disadvantaged party; and

(d) The risk of the events was not assumed by the disadvantaged party. ${ }^{18}$

\subsection{Difference with Force Majeure Clauses}

As mentioned in section 2, the force majeure clause is a major clause that deals with changed circumstances, therefore a clear distinction with hardship need to be drawn, because despite that the purpose of both of them might seem similar, they are not the same. ${ }^{19}$ However, while the hardship clause addresses circumstances in which the performance becomes more burdensome, but not impossible, Force Majeure clause addresses just that, the impossibility of performance, at least temporarily, due to the occurrence of unforeseen circumstances. ${ }^{20}$ Furthermore, the legal consequences of both clauses are different. Unlike force Majeure clauses, which usually provide for the suspension or termination of the contract when the performance has become impossible, hardship clauses usually seek to restore the equilibrium of the contract, they adjust some of the contractual terms to adapt the contractual balance which may have been upset by the unforeseen circumstances ${ }^{21}$ or parties renegotiate the contractual terms which are affected by the changed situations.

\subsection{Requirements for Triggering the Hardship Clause}

In order to trigger the hardship clause the requirements briefly are:

- Continued performance of contractual duties becomes excessively onerous

- Events are beyond parties control

- Events occur after the conclusion of the contract

- Events could not reasonably been taken into account by the disadvantaged party at the time of the conclusion of the contract

- The risk of the events was not assumed by the disadvantaged party. ${ }^{22}$

\subsection{Consequences of Hardship Clauses}

UNIDROIT Principles of International Commercial Contracts lists legal consequences of hardship in Article 6.2.3:

Effects of Hardship

(1) In case of Hardship the disadvantaged party is entitled to request renegotiations. The request shall be made without undue delay and shall indicate the grounds on which it is based.

(2) The request for renegotiation does not in itself entitle the disadvantaged party to withhold performance. (3) Upon failure to reach agreement within a reasonable time either party may resort to the court. (4) If the court finds

\footnotetext{
${ }^{18}$ Art. 6.2.2 UNIDROIT principles 2016, 2016

${ }^{19}$ Raul Pereira de Souza Fleury, (2015) Hardship: A remedy for changed Circumstances in International Commercial Contracts, p. 9

${ }^{20}$ Ibid, 10.

${ }^{21}$ Talal Abdulla AL-Emadi,"The Hardship and Force Majeure Clauses in International Petroleum Joint Venture Agreements." (2011), p. 4

22" Comparison of Commonly used Hardship and Force Majeure clauses."(2017)
} 
Hardship it may, if reasonable, (a) terminate the contract at a date and on terms to be fixed; or (b) adapt the contract with a view to restoring its equilibrium. ${ }^{23}$

Based on the above article, a justified hardship circumstance can result in the renegotiation, adjustment or termination of the contract. ${ }^{24}$ Once the unpredictable, supervening, overly burdensome and beyond control situation is verified, the hardship clause is triggered and typically, its first effect is for the renegotiation of the terms of contract by the parties. ${ }^{25}$ If the hardship claim is reasonable, the opposite party is obligated to negotiate in good faith to adapt the contract to ease the burden. A party that is in bad faith negotiating or breaking off agreement is responsible for the losses caused to the opposite party. In the event the parties do not agree, either party may apply to the court. ${ }^{26}$

In the case of hardship, a duty to renegotiate does not imply uncertainty or reduction of contractual stability. On the contrary, it gives flexibility for the parties to seek a better adaptation of the contract to the new and unpredicted situations. ${ }^{27}$ Renegotiation is seen as a ways of stabilizing the relationship between the parties because it decreases the possibility of a dispute between them.

When renegotiation fails, the result can be either the adaptation of the contract through courts or arbitrators or termination. Termination the effortless and most extreme of the solution, but it may not be the most suitable for the parties' interests, especially if both need to protect their relations or the interests of the third party concerned, and therefore they may depend on the adaptation of the contract by courts or arbitrators. ${ }^{28}$

The adaptation of a contract implies the modification of the obligations of one or both parties to the degree that the performance of the contract by the influenced party is feasible or endurable, intending to restore their balance when it has been harshly disrupted by unforeseen events. This allows the survival of a contract, but in its modified terms. However, in many jurisdictions, the only remedy for unforeseen change of circumstances is the discharge or termination of the contract. ${ }^{29}$

\subsection{Drafting Hardship Clauses}

Drafting a hardship clause in oil and gas contracts is crucial and needs to be paid more attention by drafters. Hardship clauses contain two essential parts: the first part determines the hypothesis under which the clause will apply and the second part of the clause specifies the procedure applicable in case the hardship event happens. Certain hardship clauses start with a short preamble. The usage of a preamble clarifies the philosophy behind the clause, in this manner facilitating its application by a third party, whether arbitrator or expert. The below is an example for the preamble:

In entering into this long term Contract the parties hereto agree that it is impracticable to make provision for every contingency which may arise during the term thereof; and the parties hereby agree it to be their intention that this Contract shall operate between them with fairness and without prejudice to the interests of either. ${ }^{30}$

As to the hypothesis, the wording of the clause is significant. The hardship clause should be specific, therefore a list of predetermined circumstances that would amount as to a hardship situation would be preferred, for example economic, financial, or political situations. Furthermore, it should be given that at the time the contract concluded these changed circumstances are reasonably unanticipated and lead to important disruption on the contractual equilibrium. However, the part of the hypothesis needs to give that the list of circumstances is not limited and therefore, any other circumstances not listed which satisfy the requirements of hardship would be considered as such. ${ }^{31}$

When the circumstances are determined as hardship, the second part of the clause needs to address the remedy for such changed circumstances via the renegotiation of the contract. In the clause objective, standards should be defined, by

\footnotetext{
${ }^{23}$ The UNIDROIT Principles of International Commercial Contracts, note 3

${ }^{24}$ Raul Pereira de Souza Fleury, Op.Cit, 9.

${ }^{25}$ Ibid.

${ }^{26}$ Joseph Perillo, 'Force Majeure and Hardship Under the UNIDROIT Principles of International Commercial Contracts' (1997) 5 Tulane Journal of International and Comparative $<$ https://ir.lawnet.fordham.edu/faculty_scholarship/783 >accessed 20 January 2020

${ }^{27}$ Rodrigo Momberg Uribe, 'The Effect of a Change of Circumstances on the Binding Force of contracts' ( Phd Thesis, University of Utrecht 2011)

${ }^{28}$ Ibid, 231

${ }^{29}$ Ibid, 238-239

${ }^{30}$ Marcel Fontaine \& Filip De Ly, Op.Cit, 460

${ }^{31}$ Raul Pereira de Souza Fleury, Op.Cit,21

108
} 
given, for example, that the contract's equilibrium needs to return as it was at the time of the conclusion of the contract. ${ }^{32}$ In drafting the clause, it should be considered that to require the parties to negotiate in good faith and without delay to arrive at an adjustment of the contract consistent with the standards which are defined in the clause if the conditions for a claim of hardship are met. ${ }^{33}$

Another approach that's followed in drafting the hardship clause is to address where an arbitrator or third party expert can be appointed to determine and adjustment question in case of disagreement between the parties of the contract. The clause should provide, when the parties cannot agree to re-adapt the contract, the dispute will be submitted to the judgment of third parties, arbitrators or experts.

Termination of the contracts is another consequence of hardship circumstances in oil and gas contracts. Therefore termination payments should be defined. Depending on the cause of the termination (Fault of parties, force majeure, and hardship), the termination payments are different. A well-considered and arranged termination can also serve as a protection against pointless claims of hardship. If the consequence of a successful claim of hardship is termination, the hardship clause should provide a defined termination payment in this event, the parties at least know to go in what the eventual consequence of hardship will be. ${ }^{34}$

In brief, drafters of oil and gas contracts should walk a fine line in determining the manner of parties' response to unforeseen changes of circumstances in performance. In defining the circumstances under which claims of hardship can be invoked and what occurs afterward, a certain degree of accuracy is required. However, an effort to determine too many or all the predictable consequences in contracts is a very risky exercise. Besides, drafting the clause should not be over-detailed, it may fail. By providing definite consequences for one circumstance, it might be deduced that the parties may not apply the same consequences to other circumstances. Otherwise, the language that is too-open ended concerning the duty of parties to negotiate in good faith and agree on the method of the costs of unexpected circumstances should be assigned among is expected to fail. Because those attempting to settle the dispute, whether they are courts, arbitrators or experts will not have a precise direction to make a decision.

\subsection{Hardship Clauses in KRG's PSCs}

As mentioned early, the hardship clause is important in oil and gas contracts and plays an essential role in resolving problems between parties in hardship circumstances. Nevertheless, by reading KRG Oil and gas contracts, it is noted that there is not a hardship clause in these contracts. It seems, the drafters of KRG oil and gas contracts did not separate the force majeure and hardship circumstances and combined both under the clause of force majeure. Article 40, determines the mean of force majeure, it states any event that prevents or impedes the fulfillment of all or part of the contractor's obligations. It clarifies the mean of force majeure as follow:

40.2 For the purpose of this Contract, "Force Majeure" means any event that is unforeseeable, insurmountable and irresistible, not due to any error or omission by the CONTRACTOR but due to circumstances beyond its control, which prevents or impedes execution of all or part of its obligations under this Contract....... ${ }^{35}$

Thus, the force majeure clause in KRG's PSCs may cover force majeure and hardship events. The clause determines many events that are beyond the control of the contracting parties. Apart from this clause, there is only arbitration and expert determination clause that deals with circumstances create dispute and try to resolve the dispute.

However, the hardship clause has a different purpose from the force majeure clause, as clarified early, there are differences between them. The absence of a hardship clause could be a gap in KRG oil and gas contracts. Therefore it is recommended for its future oil and gas contracts.

\subsection{Hardship Clause Comparison}

The absence of the hardship clause is noted in many oil and gas contracts. The clause is not frequently used in oil and gas contracts for the reason that force majeure clauses are now generally formulated to cover all unforeseen circumstances that give rise to hardship circumstance and the usage of economic stabilisation clauses in oil and gas

\footnotetext{
${ }^{32}$ Ibid.

${ }^{33}$ Frederick R. Fucci, Hardship and changed Circumstances as Grounds for Adjustment or Non-Performance of Contracts : Practical Considerations In International Infrastructure Investment and Finance ( American Bar Association, Section of International Law, 2006), 41

${ }^{34}$ Ibid, 43

${ }^{35}$ The Production Sharing Contrac, Dohuk Block between the Kurdistan Regional Government of Iraq and DNO Iraq As, 2008.
} 
contracts may deal with some hardship circumstances. However, these are not satisfied reasons to forget the hardship clause in oil and gas contracts.

In the sample of Indonesian PSC, the hardship is not used. Instead, the force majeure covers all unpredictable circumstances, arise during the term of the contract and this is similar to KRG's PSCs.

In the Nigerian PSC similar to the KRG's and Indonesian PSCs, the hardship clause is not used. The force majeure clause broadly covers unforeseen circumstances during the term of contracts.

In order to clarify the effect of the hardship clause, the following examples demonstrate the application of the clause.

The Bangladesh PSC model of 1997 is an example for PSCs models that contains the hardship clause as the following:

If at any time during the term of this Contract there are substantial changes in economic circumstances affecting its performance, which either Party reasonably considers is causing it to suffer economic hardship, the Parties shall meet together within thirty days after written notice of these circumstances to consider, whether any, adjustments) in the terms and conditions of the Contract are reasonably justified to alleviate the hardship. ${ }^{36}$

Another example for the hardship clause is the clause 7 in the agreement that the Phillips and the Arpet Groups made with British Gas Corporation in 1968. It states:

(a) If at any time or from time to time during the contract period there has been any substantial change in the economic circumstances relating to this Agreement and (notwithstanding the effect of the other relieving or adjusting provisions of this Agreement) either party feels that such change is causing it to suffer substantial economic Hardship then the parties shall (at the request of either of them) meet together to consider what (if any) adjustment in the prices then in force under this Agreement or in the price revision mechanism contained in Clauses 4, 5 and 6 of this Article are justified in the circumstances in fairness to the parties to offset or alleviate the said Hardship caused by such change.

(b) If the parties shall not within ninety (90) days after any such request have reached agreement on the adjustments (if any) in the said prices or price revision mechanism which are to be made then the matter may forthwith be referred by either party for determination by experts to be appointed in the manner set out in Article xviii hereof save that the appointment of the third expert referred to in Clause 1(c) of that Article shall in 16 [1982] 1 Lloyd's Rep 262, 264-265; the clause is also available in E McKendrick Contract Law (2nd edn OUP Oxford 2005) 4394407 any event be made by the Minister of Power in consultation with the Lord Chancellor.

(c) The experts shall determine what (if any) adjustments in the said prices or in the said price revision mechanism shall be made for the purposes aforesaid and any revised prices or any change in the price revision mechanism so determined by such experts shall take effect six (6) months after the date on which the request for the review was first made. ${ }^{37}$

As indicated, oil and gas contracts, frequently do not contain the hardship clause, while this clause is effective in the case of economic hardship.

\section{Conclusion}

In a long-time oil and gas contract, circumstances may change and lead to disputes. There are certain contractual clauses that can prevent the contract from arising disputes in the lifetime of the project and play an important role to avoid disputes. Force majeure and hardship clauses are crucial clauses for dispute avoidance in changed circumstances which are beyond the control of contracting parties. This article has provided a clear understanding of these clauses, via defining and explaining their consequences as well as indicating the differences between the clauses. It has given essential points to obey and pay attention to drafting the clauses in oil and gas contracts. Force majeure and hardship clauses in KRG's PSCs have been examined and compared with Indonesian and Nigerian PSCs. It has been founded that the PSC of KRG contains the force majeure clause that combines force majeure and hardship circumstances. The clause clarifies that in a case of force majeure delay, default, breach or omission of the contractor is not considered as a failure to perform the contract or the subject of a dispute. It also mentions the notifying of the government by the contractor in the event of force majeure.

The force majeure clause determines the mean and events of force majeure, despite presenting events in a list, still, in certain events, they are examples rather than limitation. The force majeure clause in the PSC of KRG is very wide, it

\footnotetext{
${ }^{36}$ Bangladesh Model Production Sharing Contract , 1997, Article 13.14

${ }^{37}$ The Agreement between Phillips and the Arpet Groups and British Gas Corporation in 1968, clause 7. 110
} 
could be more precise by determining only force majeure events. As indicated in this article, force majeure events are different from hardship evens, therefore, it is recommended to review the force majeure clause and consider the insertion of the hardship clause in the future PSCs of the KRG.

\section{References}

Fontaine Marcel \& De LyFilip, Draftin International contracts: An Analysis of Contract Clauses (Transnational Publishersp2006)

Fucci Frederick R., Hardship and changed Circumstances as Grounds for Adjustment or Non-Performance of Contracts : Practical Considerations In International Infrastructure Investment and Finance ( American Bar Association, Section of International Law, 2006)

Langenkamp Robert Dobie, Handbook of oil industry Terms and phrases ( $6^{\text {th }}$ edn, PennWell, 2014)

McKendrick Ewan, Contract Law ( $5^{\text {th }}$ edn, Oxford University press, 2012)

Firoozmand Mahmoud Reza, 'Force Majeure Clause in Long-Term Petroleum Contracts: Key Issues in Drafting'(2006) 24/3 Journal of Energy \& Natural Resources Law 423

Greenfield Don \& Rooney Bob, 'Aspects of International Petroleum Agreements' (1999) 37 Alberta Law Review 352 Salih Mohsin Shareef and Salih Rdhwan Shareef, 'Strategy of Oil Contract Negotiation' (2015) 6 /9 International Journal of Business and Social Science 168

Uribe Rodrigo Momberg, ' The Effect of a Change of Circumstances on the Binding Force of contracts' ( Phd Thesis, University of Utrecht 2011)

AL-EmadiTalalAbdulla,"The Hardship and Force Majeure Clauses in International Petroleum Joint Venture Agreements." (2011)

Fleury Raul Pereira de Souza, (2015) Hardship: A remedy for changed Circumstances in International Commercial Contracts

"Comparison of Commonly used Hardship and Force Majeure clauses."(2017)

The UNIDROIT Principles of International Commercial Contracts, 2016

DavidRene, 'Frustration of Contract in French Law' (1946) 28 (3/4) Journal of Comparative Legislation and International Law <https://www.jstor.org/stable/754645?seq=1\#metadata_info_tab_contents> accessed 20 November 2019

Melis Werner, 'Force Majeure and Hardship Clauses in International Commercial Contracts in View of the Practice of the ICC Court of Arbitration' (1984) 1 Journal of International Arbitration <http://www.kluwerlawonline.com/abstract.php?area=Journals\&id=JOIA1984023> accessed 7 December 2019

Perillo Joseph, 'Force Majeure and Hardship Under the UNIDROIT Principles of International Commercial Contracts' (1997) 5 Tulane Journal of International and

Comparative<https://ir.lawnet.fordham.edu/faculty_scholarship/783>accessed 20 January 2020Contracts:

The Production Sharing Contrac, Dohuk Block between the Kurdistan Regional Government of Iraq and DNO Iraq As, 2008.

Production Sharing Contract for Yapen Block in 1999, Between Perusahaan PertambanganMinyak Dan Gas Bumi Negara (Pertamina) and Apex(Yapen) LTD..

Production sharing Agreement, Strategic Alliance Agreement, 2011, Between Nigerian Petroleum Development Company Limited and Atlantic Energy Drilling Concepts Nigeria Limited for the Development and Production of OML .

The Agreement between Phillips and the Arpet Groups and British Gas Corporation in 1968 Bangladesh Model Production Sharing Contract, 1997. 